\title{
“Para que esse drama?": uma experiência de ensino de Teatro entre professores em formação
}

\section{"Why that drama?": an experience of theater teaching among teachers in education}

Everton Ribeiro ${ }^{1}$

Rafael Siqueira de Guimarães ${ }^{2}$ 


\section{Resumo}

0 intuito deste trabalho foi pesquisar sobre o drama como método de ensino de teatro, desdobrada em uma pesquisa orientada desde a ação prática. Por meio de um traçado histórico e significativo do drama - também conhecido na Inglaterra por process drama e drama in education, analisamos uma prática em pesquisa-ação desenvolvida com professores em formação a partir de uma série de episódios concebida por meio da peça A falecida, de Nelson Rodrigues, como pré-texto. O processo analisado permitiu um olhar mais aprofundado a respeito da articulação desse método de ensino anglo-saxônico com a transversalidade proposta para o currículo brasileiro. Conceitos como experiência, formação e reprodução permeiam toda a fundamentação e análise da pesquisa, bem como aqueles conceitos próprios do drama como método de ensino.

Palavras-chave: Drama; experiência; ensino de teatro

\section{Abstract}

The aim of this work was to inquire about drama as a method for the theater teaching, unfolded in a research oriented from the practical action. By means of a historical and significant tracing of the drama - also known as process drama and drama in education, we analyze a practice in action-research developed with teachers in education from a series of episodes that were composed through the play The deceased, by Nelson Rodrigues, as a pre-reading. The analyzed process allowed a deep look at the articulation of this anglo-saxon method with the transversality proposed for the Brazilian curriculum. Concepts such as experience, learning and reproduction permeate all the substantiation and analysis of the research, as well as those concepts that belong to process drama.

Keywords: Drama; experience; theatre teaching 


\section{Ensino de Teatro na Educação Básica: um desafio contemporâneo}

Os Parâmetros Curriculares Nacionais discutem a importância da Arte na escola, pois esta "constitui uma possibilidade para os alunos exercitarem suas corresponsabilidades pelos destinos de uma vida cultural individual e coletiva mais digna, sem exclusão de pessoas por preconceitos de qualquer ordem" (Brasil, 1997, p. 38). Quando o professor de Arte ensina teatro no contexto escolar espera o educando recrie sua realidade e reflita, também, sobre o contexto social do qual é pertencente.

Os desvelamentos da relação entre docente e educando têm sido um objeto de estudo no tocante à prática teatral como pesquisa, no intuito de apurar conhecimentos específicos do Teatro. A processualidade da experiência estética faz emergir diferentes linhas de fuga sobre aquilo que se pesquisa, por meio de uma "dimensão ética, ideológica e política, tanto quanto epistemológica" (Cabral, 2006, p. 35). Deste modo, tomando por base o aspecto social do teatro, caso o drama seja bem concebido, "ele cumpre com sua função política, estética e pedagógica: se ele for ruim passa a ser um desserviço para a fruição artística" (Ribeiro, 2013, p. 26259) ${ }^{3}$. No que se refere ao process drama, "as proposições feitas pelo professor são encaminhadas por um ponto de vista específico, no entanto há a possibilidade de propor um novo episódio que focalize a situação por outra perspectiva" (Ribeiro, 2013, p. 26259).

De qualquer forma, ainda lidamos, no espaço escolar, com a dificuldade de que ensinar teatro não está vinculado a montar uma peça teatral. Podemos perceber estes equívocos ao nos depararmos com atividades pouco pedagógicas, tais como: a apresentação teatral vinculada a uma data comemorativa, a montagem de um grupo de teatro na escola mediante seleção daqueles que já tem algum "talento", o uso de propostas dramáticas com enfoque terapêutico, o ensino de teatro através do estudo da história do teatro ocidental e/ou o convite a um grupo de teatro - geralmente amador - que vende suas peças "didáticas" e as exibe a todas as escolas da região.

Desde 2003, a especificidade de cada área artística (Artes Visuais, Dança, Música e Teatro) foi refletida numa formação de professor com habilitação em uma destas áreas para não incorrer na superficialidade construída nas antigas formações em Educação Artística, cujo foco de trabalho do professor acabava sempre sendo as Artes Plásticas, muitas vezes por meio de atividades que apenas reproduziam uma técnica. Até a criação da Lei 9.394/96, a inclusão da arte no currículo escolar, com o título de Educação Artística, era tida como "atividade educativa" e não como uma disciplina. Isso acabou balizando as aulas em uma aprendizagem reprodutiva, cuja qualidade dos saberes inerentes à arte se esvaiu. Somente com a nova Lei que estabelece as Diretrizes e Bases da Educação Nacional é que o ensino da arte se tornou obrigatório e deixou, em partes, de ser visto como uma atividade, um mero "fazer por fazer", atribuindo espaço para o novo.

3 Este artigo é uma compilação de um estudo liderado pelo pesquisador Everton Ribeiro, entre os anos de 2013 e 2014. Portanto, algumas publicações já realizadas por ele sobre temas correlatos serão referidas nesta investigação quando algumas paráfrases ou citações diretas forem incorporadas a este trabalho, em respeito aos desmembramentos éticos de pesquisa. 
A função da escola está limitada em ensinar "aquilo que já se sabe" (Figueira, 1995, p. 12), por conseguinte é evidente o desalinho entre aquilo que se deveria aprender e aquilo que - de fato - se aprende neste espaço. Jean-François Lyotard (2002) contribui com esta reflexão por meio de suas metanarrativas, afinal "a transmissão dos saberes não aparece mais como destinada a formar uma elite capaz de guiar a nação em sua emancipação. Ela fornece ao sistema os jogadores capazes de assegurar convenientemente seu papel juntos aos postos pragmáticos de que necessitam as instituições" (Lyotard, 2002, p.89).

O privilégio dado à meritocracia nos processos de avaliação em estabelecimentos escolares é tomado como medida "não apenas as representações e as práticas dos agentes, mas também a organização e o funcionamento da instituição" (Bourdieu; Passeron, 2011, p. 169). Quase nunca "o estudante é convidado a refletir sobre situações de opressão ou sobre a marginalização e/ou hierarquização dos conteúdos estabelecidos no programa escolar" (Ribeiro; Silva, 2014, p. 33-34). Eis, portanto, a importância da experiência estética na construção de conhecimentos.

Um dos saberes primeiros, indispensáveis a quem, chegando a favelas ou a realidades marcadas pela traição a nosso direito de ser, pretende que sua presença se vá tornando convivência, que seu estar no contexto vá virando estar com ele, é o saber do futuro como problema e não como inexorabilidade. É o saber da História como possibilidade e não como determinação. $\mathrm{O}$ mundo não é. $\mathrm{O}$ mundo está sendo. (Freire, 1996, p. 76)

Ainda que se pense a transformação de um currículo escolar, é relevante assinalar a reprodução que o compõe e, mais ainda, o paradigma desenhado pela formação docente nas instituições de ensino superior. O molde estabelecido na prática docente é confrontado "por uma teoria tradicional, que prioriza a metodologia, a didática, o planejamento, a avaliação e a eficiência" (Ribeiro; Silva, 2013, p. 34).

No caso dos professores, apesar de haver uma formação específica, formal, profissional, para exercer a docência - e mesmo supondo que todos os professores recebessem uma excepcional formação, com fundamentação teórica crítica e sólida - quando eles se deparam com a prática escolar, interna e externa à sala de aula, e diante dos imprevistos e desafios que surgem, a tendência de reproduzirem o modelo que vivenciaram é muito mais forte do que a de realizarem tentativas de uma nova prática, um método diferente. (Gonçalves; Gonçalves, 2010, p. 73-74)

Com base numa "pedagogia que privilegia a imitação de um modelo, a prática docente é pensada através de um habitus herdado como agente pedagógico, pelo qual se constrói uma certeza do que é ser professor e do que é ser aluno" (Ribeiro; Silva, 2013, p. 34). Para Pierre Bourdieu (2002, p. 83), "habitus é um operador, uma matriz de percepção e não uma identidade ou uma subjetividade fixa". Habitus é um produto histórico, um sistema aberto e afetado por novas experiências, portanto passível de mudança, não obstante sua resistência. 


\title{
Que drama é esse?
}

O processo dramático explora conhecimentos por meio de uma experiência investigativa. Este método se baseia numa na sucessão de episódios fundamentadas em elementos próprios da teatralidade. Inicialmente, define-se um tema norteador para sua composição e processualidade. Assim, na linha tênue entre realidade e imaginação, o processo dramático sincroniza diferentes realidades.

Entre ficção e realidade, o professor-atuante ${ }^{4}$ faz emergir o espaço potencial da experiência. "O papel ficcional representado por todos os participantes no contexto do drama estabelece uma zona de conforto para a discussão de temas, muitas vezes, censurados na infância e na adolescência" (Ribeiro, 2013, p. 26259). É fundamental o potencial de experiência emerso do drama como método de ensino, pois "o desafio da escola e dos projetos educativos que orientam nossa prática está no fato de que, para compreender a cultura de um grupo ou de um indivíduo que dela faz parte, é necessário olhar a sociedade onde o grupo ou o indivíduo estão e vivem" (Gusmão, 2000, p. 16).

Ao explorar ações irônicas em seu papel, o professor-atuante introduz contradições ao longo do processo. Deste modo, explicita, intencionalmente, que "podemos não estar exatamente querendo significar o que estamos dizendo" (O'Neill, 2006, p. 10). Por isso, é incontroversa a premência de que quem participa de um processo dramático adentre um universo imaginário. Esta máxima do drama está estritamente relacionada com a proposta do happening como uma forma livre de teatro:

\begin{abstract}
No happening, o limite entre o ficcional e o real é muito tênue e nesse sentido a convenção que sustenta a representação é constantemente rompida. Esta ruptura se dá de várias formas, como pelas situações de imprevisto que caracterizam os happenings - o público não sabendo o que vai acontecer - e nesse sentido entrando em "situações de vida" em que pode ser instado a participar a qualquer instante. (Cohen, 2004, p. 133)
\end{abstract}

A criação de espaços de ficção permite estar entre diversos lugares, onde é possível (re) escrever narrativas junto aos participantes: histórias, indivíduos, convenções e artefatos. O caráter estético é requerido e permite, pelas interlocuções artísticas, ampliar a percepção, estabelecendo novos posicionamentos. O espaço concebido tem o potencial de proporcionar experiência, de despertar olhares que quebrem com o estabelecido, com os paradigmas:

[...] drama é essencialmente uma interação dramática cujo processo mobiliza os sentimentos e o intelecto dos participantes com o objetivo de compreender seus significados e implicações. A imaginação torna-se, assim, central ao desenvolvimento do processo, de uma forma particular: a atividade dramática requer que o participante adote conscientemente um 'como se', simultaneamente mantendo dois mundos em mente: o presente ou real e o ausente ou fictício. (Cabral, 2010, p. 1)

4 Esta foi a tradução escolhida para teacher-in-role por considerarmos a vivência no processo dramático melhor alinhada à atuação, porque nela "abre-se espaço para o imprevisto, e, portanto, para o vivo, pois a vida é sinônimo de imprevisto, de risco". (Cohen, 2004, p. 97) 
O saber da experiência é a máxima do drama como método de ensino. Para Jorge Larrosa, experiência compreende aquilo que nos toca, que nos passa, que nos acontece. Deste modo, "o sujeito da experiência seria algo como um território de passagem, algo como uma superfície sensível que aquilo que acontece afeta de algum modo, produz alguns afetos, inscreve algumas marcas, deixa alguns vestígios, alguns efeitos" (Larrosa, 2002, p. 24). A condução de um processo dramático exige do professor desprendimento da verticalização imposta pela educação tradicional. Não há controle do desfecho e dos conflitos apresentados. O participante integra o processo e, portanto, está livre para lê-lo e interpretá-lo espontaneamente.

\section{A pesquisa-experiência: participantes e pré-texto}

Os participantes da pesquisa totalizaram 27 (vinte e sete). A princípio, a proposta do projeto era desenvolver o processo com dois grupos distintos de até 25 (vinte e cinco) participantes cada, sendo um de professores de Arte em formação e outro de professores já atuantes na educação básica. No entanto, após algumas definições pragmáticas de calendário e a observação de que boa parte dos estudantes, em formação na licenciatura, já atuavam como professores da rede municipal, estadual ou particular, havia a heterogeneidade na composição do grupo. Assim, o grupo foi composto por 25 (vinte e cinco) alunos da Licenciatura em Artes em diferentes períodos do curso, tendo sido contemplada todas as fases de formação - do 1ำ ao 4을 ano, 1 (uma) aluna do curso de Gestão Desportiva e do Lazer e 1 (uma) aluna do curso de Serviço Social, ambas com experiências em teatro em espaços não-formais.

O processo foi concluído por 25 (vinte e cinco) participantes, ou seja, houve apenas duas desistências ao longo da experiência. A participação feminina foi maior (88\%), tendo participado do processo apenas três homens (12\%). A média de idade dos participantes foi 30 anos, tendo o mais jovem 17 e a mais velha 60 . Pouco mais da metade (56\%) dos participantes atuam ou já atuaram como professores de arte na educação formal ou não-formal.

O pré-texto escolhido para a criação da sequência de episódios do drama foi a peça "A falecida", de Nelson Rodrigues. É importante dizer que em nenhum momento os participantes foram comunicados sobre a peça e, tampouco, tiveram acesso a qualquer material que indicasse a obra de Nelson Rodrigues como ponto de partida.

\footnotetext{
A falecida conta a história de uma mulher frustrada do subúrbio carioca, a tuberculosa Zulmira, que não vê mais expectativas na vida. Pobre e doente, sua única ambição é um enterro luxuoso. Quer se vingar da sociedade abastada e, principalmente de Glorinha, sua prima e vizinha que não lhe cumprimenta mais. Zulmira tem uma relação de competição com a prima, chegando até mesmo a ficar feliz quando sabe que a seriedade da prima provém de um seio arrancado pelo câncer. O marido, Tuninho, está desempregado e gasta as sobras da indenização jogando sinuca e discutindo futebol. (Ribeiro, 2013, p. 26261).
}

O esquema seguinte apresenta uma estrutura dramática concebida de acordo com algumas premissas de Neelands (1990) a respeito de ações que promovam o potencial de experiência. Cada episódio corresponde a um dia específico de aula, com periodicidade semanal. Todo o processo foi registrado em audiovisual. A descrição 
de cada episódio foi adaptada de uma publicação anterior realizada pelo pesquisador Everton Ribeiro5.

A) VELÓRIO - a ambientação do espaço foi dada por uma estrutura pobre, caixão simples, sem decoração, com várias cadeiras espalhadas no entorno, agrupadas de acordo com o grau de relação com a falecida. Para facilitar a narrativa do drama de A falecida, o professor-atuante (no papel de um agente da funerária) recebeu todos os envolvidos, um a um, cumprimentando de acordo com seu papel (familiares, amigos, vizinhos), agradecendo a presença no velório. Ao final da recepção, anunciou aos participantes que estivessem à vontade até que o padre chegasse, pois será uma oportunidade para levantarem lembranças da falecida. Na entrada, cada participante recebeu um bilhetinho aleatório escrito por Zulmira. Foram introduzidas questões pelo professor-atuante neste momento: $O$ que pensar da morte? O que pensar da falecida? Quem é esse que está ao seu lado? Depois dessa discussão em grupos, o padre chegou e leu o obituário de Zulmira publicado no jornal da cidade, ressaltando a "suntuosidade" do enterro. Este foi um importante elemento de ironia deste episódio, ao passo que, visivelmente, o enterro foi paupérrimo. Depois da bênção, foram servidos cafezinho e biscoitos com o pretexto de uma discussão coletiva, pelos participantes, sobre a memória de Zulmira.

B) IMPRENSA - uma arara foi disposta com seis figurinos distintos (camisa do Santos, xale, chapéu, paletó, jaleco e camisa feminina). Estes figurinos representavam, respectivamente, os seguintes personagens: Tuninho, Madame Crisálida, Timbira, Pimentel, Dr. Borborema e Glorinha. Os participantes foram divididos em seis equipes de números pares. Um deles vestiu o figurino como uma espécie de anfitrião dos demais convidados. Estes convidados assumiram o papel de repórteres para investigar questões sobre a relação do anfitrião com a falecida. A premissa é a de que todos os anfitriões conheciam Zulmira e estiveram com ela nos dias que antecederam sua morte. Caso os participantes não descobrissem um papel com frases em seu figurino, foram orientados a vasculharem-no. Este papel possuía duas frases ditas pelo personagem caracterizado na peça. Os participantes utilizaram as frases como pré-texto para argumentarem ao longo do interrogatório.

C) PERÍCIA - nesse momento, o grupo foi dividido em equipes de peritos e receberam um pacote de estímulo composto ${ }^{6}$, anunciado pelo professor (no papel de investigador) ser a gaveta da cômoda de Zulmira, com vários elementos que se referiam ao conflito da protagonista (diário, fotos, jornais, objetos pessoais, adereços, orçamento, radiografia, laudo de exame etc.). O objetivo foi conhecer e investigar o material, a partir das relações estabelecidas no velório e na visita aos conhecidos da falecida. Depois da análise das equipes, eles foram arguidos sobre: Quem é essa mulher? 0 que aconteceu com ela? Este episódio é chave para discutir o desenlace da vida de Zulmira e sua morte.

\footnotetext{
5 A publicação referida trata-se do artigo "Para evitar o alienigenismo: uma proposta de process drama através da mediação irônica do professor-personagem", apresentado e publicado nos anais do XI Congresso Nacional de Educação - EDUCERE, ocorrido em 2013, na cidade de Curitiba - PR, promovido pela Pontifícia Universidade Católica do Paraná (PUCPR).

6 De acordo com John Somers, o estímulo composto guia história, papéis e ambientes. "A energia e o interesse gerados pelo estímulo composto promovem o 'reforço' inicial para a criação da história[...] serve como uma referência contínua no processo de criação". (Somers, 2011, p. 178)
} 
D) CARTOMANCIA - neste último episódio, o professor-atuante assumiu o papel de Madame Crisálida, a cartomante charlatã, que fez previsões irônicas para cada participante, ridicularizando o futuro farsesco, como ocorreu com a falecida. No entanto, uma nova personagem (a mãe de Zulmira) irrompeu a cena e trouxe contribuições para o desfecho do drama.

Para John Somers (2011, p. 179), "os elementos da história que cada artefato representa devem, quando justapostos, criar uma rede de relacionamentos que nem sejam rapidamente compreendidos para evitar que a história torne-se imediatamente óbvia, nem tão distantes um do outro para que as possibilidades narrativas possam emergir". Ao longo do processo de drama, o desenlace pode sofrer algumas alterações, que de fato aconteceram.

\section{O processo do drama: percepções do professor-atuante}

Para a compreensão do processo e de como ele foi conduzido, é importante que este seja narrado, no intuito de proporcionar maiores detalhes sobre a pesquisa-ação como um todo. A partir de agora, como professor-atuante, adotarei nesta seção o papel de narrador. Narrador não apenas no sentido de descritor de fatos, mas de extrapolar a privação de intercambiar experiências, pois, para Walter Benjamin, "a experiência que passa de pessoa a pessoa é a fonte a que recorreram todos os narradores. $E$, entre as narrativas escritas, as melhores são as que menos se distinguem das histórias orais contadas pelos inúmeros narradores anônimos" (Benjamin, 1994, p. 198). Neste sentido, este tipo de narrativa proposto está diretamente relacionado ao drama como método de ensino, pois, como permeia a realidade, inclui também nossa existência, afinal não haveria possibilidade de construirmos algo para além do momento da experiência, sem as perspectivas de enquadramento de uma história.

\section{Primeiro Episódio}

No início do drama foram dadas algumas indicações aos participantes a respeito do processo: "não precisam se preocupar em inventar algo novo"; "sejam espontâneos"; "deixem as coisas acontecerem". Era o velório! Todo o cenário foi criteriosamente concebido para representar uma cerimônia paupérrima: caixão, símbolos religiosos, bolachas de maisena e cafezinho. Tudo estava perfeitamente disposto em uma semi-arena na caixa preta e com iluminação alusiva ao ambiente. Os participantes aguardavam fora da caixa preta. Fiz minha preparação corporal e me concentrei para aquele momento: foi a primeira vez que recorri a artifícios de meu trabalho de ator no exercício da docência, logo percebi a magia que seria a condução deste processo e da especificidade deste trabalho como professor que acredita na experiência, um professor-atuante. Abri a porta como um agente funerário, enunciei a notícia da morte com naturalidade, requisitando para que primeiro os familiares adentrassem o recinto e, posteriormente, os amigos da família. Outras pessoas que não eram participantes do processo e transitavam pelo saguão naquele momento - afinal era um dia de aula normal - pararam para escutar e ficaram muito curiosos para saber o que 
ocorria naquela situação. Em determinada ocasião, inclusive, uma funcionária dos serviços gerais entrou no teatro por algum motivo e recuou rapidamente, fechou a porta para não ser vista, porque acontecia o velório. Ali, eu percebi que a sutileza entre o real e o ficcional se concretizara, pois, ordenadamente, sem perguntas, todos preencheram os espaços vazios, como familiares ou amigos, agindo da forma estabelecida por seu primeiro impulso. Entreguei o envelope para que alguém da família lesse o obituário publicado no jornal local.

Após a leitura do obituário, alguns comentários esparsos foram realizados entre os participantes. Havia um clima de muita tensão no ar. Uma participante chorava o tempo todo, após ter assumido o papel de familiar da falecida. A sensação era verdadeiramente a de um velório. Alguns emitiam palavras de consolo, outros ficavam em silêncio. Alguns contavam piadas para se distraírem e afastar a tristeza instaurada, outros cogitavam arriscar aspectos da vida daquela mulher. Em determinado momento, passei com uma caixinha e distribui alguns papeizinhos manuscritos por Zulmira, os quais era desejo da falecida, fossem entregues durante seu velório. A ordem foi dada por sua mãe, que não teve estrutura para comparecer à cerimônia. Cada um dos presentes pegou um dos papéis e incorporou seu material à discussão que foi suscitada. Posteriormente a polícia reuniu estas frases e criou um dossiê de investigação sobre a morte de Zulmira.

Após a inserção dessas frases no contexto do drama, novos depoimentos surgiram extremamente importantes para que a condição da falecida em vida fosse refletida. Gostaria de apontar especialmente duas manifestações por terem caracterizado a natureza do drama, no que diz respeito à assunção de papéis. Uma participante assumiu o papel de prima da falecida, muito ofendida, ao ler a frase "Eu quero um enterro como nunca houve aqui, um enterro que deixe a minha prima possessa". Ela comentou algo do tipo "eu nunca desejei mal a ela, veja se isso é coisa de se dizer, me deixar possessa por causa do enterro". Em seguida, uma outra participante assume o papel de tia da falecida, mãe desta prima, e chama a atenção dela para que ela pare de ter este tipo de atitude no velório e que, pelo menos, respeitasse sua prima neste momento. Uma outra participante interferiu na discussão exaltando a frase escrita pela falecida em 11 de junho de 2013: "Tudo menos beijo! Beijo, não!". A participante no papel de prima interpõe outro escândalo: "Então ela era prostituta!". Assim, acirram-se os burburinhos, alguns religiosos chocados com a audácia da prima, outros rindo do bafafá. Em seguida, uma participante - que assumiu o papel de enfermeira - faz uma revelação bombástica: no dia em que Zulmira foi fazer o exame no hospital vizinho, ela lhe trouxe uma receita de medicamento. Ela tossia bastante. No entanto, o medicamento não estava disponível. Mas, como ela ficou muito compadecida com o estado da paciente encontrou um lote do remédio com data de validade vencida e resolveu entregar assim mesmo para que ela pudesse iniciar o tratamento. Ela relatava tudo de forma muito preocupada e muito tensa com toda a situação. Ela chorou bastante. E várias vezes disse que se sentia culpada. Algumas pessoas presentes no velório condenaram a prática dela, de forma bastante incisiva. Ela chorou mais e ficou ainda mais preocupada com a situação. Considerei sua atitude muito corajosa, pois me lembro que a frase que ela tinha lido durante a entrega dos manuscritos foi 
justamente a do dia 24 de junho de 2013, dois dias antes da morte da falecida, em que esta relatava sobre a consulta médica que ela recebeu: "Aquela médica me fez um exame matadíssimo - uma vergonha de exame - e no fim de tudo teve a coragem de se virar pra mim e disse que eu não tinha nada! Nada!".

A atitude da enfermeira foi muito importante, pois abriu margem para discutir o estado de saúde daquela mulher. O clima já estava bastante tenso e nesse momento a tensão aumentou com manifestações do tipo: "Ah, então você não sabia que não pode entregar remédio vencido?"; "Então você acha que não tem problema nenhum fazer o que você fez?". Foi uma sequência de ironias bombardeadas sobre a enfermeira. A atenção foi desviada quando alguém começou a especular sobre a real causa da morte da mulher.

Neste momento, intervi na ação propondo a entrada de mais duas participantes. Duas estudantes haviam chegado atrasadas e permaneceram como espectadoras do processo, pois, segundo elas, não havia nenhuma possibilidade de interferir naquilo que estava acontecendo. O relato delas nos leva a inferir que o drama só acontece enquanto experiência. Não faz sentido assisti-lo, pois o real e o ficcional precisam ser vividos de forma simultânea, e não simplesmente observados.

Lembro-me que no papel de observadoras, essas participantes achavam muito engraçado o que estava acontecendo durante o velório. Mas quando eu as convidei para entrar "em cena" como ministras da igreja para fazer a oração solicitada pela família, a postura delas foi totalmente diferente, de total seriedade, quase de total confirmação do espaço ritualístico que o processo de drama requer. E o teatro também, de uma forma geral. Após as orações foi entoado por todos os presentes um cântico de igreja.

O cântico começou logo depois da oração, espontaneamente, por uma participante e, gradativamente, todos o entoavam. Era hora de encerrar o episódio quando se acentuaram as especulações sobre a morte da falecida: "mas ela morreu de quê"? Para respeitar o momento difícil da família, pedi educadamente aos amigos que fizessem sua última despedida, pois pela decisão da mãe de Zulmira, não poderiam acompanhar o enterro. Foi pedido para que todos se retirassem aos poucos, com respeito, e sob as homenagens da funerária.

Entre estes momentos, todos os participantes conversavam, se serviam de café, discutiam coisas corriqueiras, e distribuíam bolachas, lembro-me de uma participante que assumiu quase o papel de uma garçonete. Quando alguém reclamou da quantidade de açúcar no café, senti-me na obrigação de defender a funerária, já que eu era agente funerário. Ela disse: "Este café está muito doce". Eu disse: "Mas foi você quem adoçou". Este comentário ocorreu logo na saída para o enterro.

Quando pedi que os familiares fizessem sua última despedida, uma das participantes se pendurou - a que mais chorava - se jogou sobre o cenário, que era um caixão de papelão, correndo o risco de derrubá-lo. A composição do cenário era composta pelo caixão (apenas o formato do caixão, feito em papelão Paraná, que é um papelão de alta gramatura e rigidez) sobre o qual havia um tecido com estampa de mau gosto e símbolos religiosos, tais como São Francisco de Assis, um rosário, duas velas em pires (que serviam como castiçais), uma mesa na lateral com uma gar- 
rafa térmica de café, copinhos de plástico, açucareiro e uma bacia com bolachas de maisena.

Um comentário muito engraçado e que depois virou motivo de piada em outros episódios, foi quando uma das participantes, que consolava a que chorou praticamente durante todo este episódio, disse: "Cadê sua fé, você não tem fé? Veja este Santo. Eu não sei o nome desse Santo, mas veja o Santo com os pulmões de fora. Esse pulmão tão rosado". Ela foi certamente inspirada pela frase de Zulmira "Ai, que ronqueira no meu pulmão", a qual foi retirada no início do episódio.

Após encerrado o episódio do dia, eu criei como hábito fazer uma roda de conversa com todos para que eles relatassem sobre a experiência, sobre suas impressões em relação ao processo vivido naquele dia. A principal manifestação de todos sobre a vivência foi a importância da atmosfera ${ }^{7}$ que o professor estabeleceu na entrada para o velório:

A atuação do coordenador (professor/diretor) na ativação da tensão dramática e das formas de resolução de conflitos é a base da prática e reflexões pedagógicas de Dorothy Heathcote, para quem a tensão é o pivô crítico que gera a energia do drama; sem ela, ele não acontece. (Cabral, 2010, p. 2)

Eles relataram novamente sobre algumas piadas que foram contadas em uma rodinha para tentar amenizar a tensão que foi estabelecida no local, reforçaram a sensação de estar mesmo em um velório, alguns consideraram que o agente funerário podia ser um amigo da família, e as participantes que chegaram atrasadas, confirmaram a ideia de que, enquanto espectadoras, elas acharam as coisas muito engraçadas. Mas quando passaram a compor o velório elas compreenderam a atmosfera que havia se estabelecido de acordo com a tensão enquanto premissa de um processo em drama.

\section{Segundo Episódio}

No segundo episódio seis participantes assumiram personagens (agente funerário, amante, cartomante, marido, médica e prima) para uma entrevista promovida através de uma coletiva de imprensa. É importante indicar que alguns papéis podem aparecer em mais de um episódio, o que de fato aconteceu, mas não necessariamente é o mesmo participante que assumirá aquele papel continuamente. Quem escolheu os participantes que assumiriam os papéis fui eu, considerando minha percepção pelo perfil e pelo insight recebido pelo grupo naquele momento, em consonância com a fenomenologia de Merleau-Ponty, cuja leitura é a de que "obtém-se a comunicação ou compreensão dos gestos pela reciprocidade entre minhas intenções e os gestos do outro, entre meus gestos e intenções legíveis na conduta do outro" (Merleau-Ponty, 1996, p. 251). O cenário da coletiva de imprensa já estava montado. Cada cadeira tinha uma identificação com a nomenclatura da relação deste personagem com Zulmira. Cada um sabia qual personagem deveria assumir. E antes de se posicio-

7 Segundo Michael Chekhov (1996), a base da criação da atmosfera cênica é a concentração. Quando concentrado, o ator estará com toda sua essência em movimento, com seu pensamento direcionado para a verdade em cena. 
nar este deveria vestir o figurino de seu personagem:
a) MARIDO - camiseta do Santos;
b) CARTOMANTE - xale;
c) AGENTE FUNERÁRIO - chapéu;
d) AMANTE - paletó;
e) MÉDICA - jaleco;
f) PRIMA - camisa feminina.

Antes de começar a coletiva de imprensa, eu orientei apenas os participantes que seriam entrevistados de que em seu figurino estava fixado um papel com duas frases que contribuiriam para seu depoimento aos repórteres. Estas falas foram extraídas do texto original - com exceção das falas da prima, que não aparece na peça de Nelson Rodrigues.

Eu assumi o papel de organizador da coletiva de imprensa, então organizei o espaço, orientei primeiramente os entrevistados, dei as indicações aos repórteres e determinei o tempo de entrevista a todos: 15 minutos. Enquanto eu orientava os entrevistados, os repórteres se organizavam em duplas ou trios, definiam quem eles entrevistariam e elaboravam suas perguntas para a entrevista. O tempo de entrevista foi respeitado. Após o término, percebi que era necessária uma socialização dos depoimentos aos repórteres no contexto do drama. Instantaneamente, solicitei a minha colega de pesquisa, que estava acompanhando o episódio neste dia, para que assumisse o papel de investigadora de polícia e arguisse os repórteres a respeito de informações e contradições nos relatos dos entrevistados. Como ela aceitou prontamente o pedido, rapidamente ajeitamos a bancada para uma coletiva de inquérito, contribuindo para que as informações prestadas pelo conjunto de jornalistas fossem fidedignas.

A postura do professor é a daquele que desafia os pressupostos do texto ou pré-texto e aqueles introduzidos no decorrer do processo, pelo grupo, investigando através do drama as motivações ocultas que determinaram as ações e atitudes de opressão. (Cabral, 2008, p. 39)

Os repórteres expuseram suas considerações sobre cada entrevistado, enquanto a investigadora de polícia tomava nota de tudo. Sobre a médica comentaram que ela disse ser amiga da família, relatou que a falecida tinha problemas sentimentais, era fragilizada, que o problema não era no pulmão, que ela usava remédio para depressão (tarja preta) e medicamentos para tosse. O marido disse ter 35 anos, mostrou-se abalado, informou que a esposa morreu nos seus braços, ele tinha um caso com a prima da mulher e frequentava a cartomante, que era conhecida da família. Em contrapartida, a cartomante revela que não era tão íntima assim, que nos búzios viu uma loira, relutou a dar mais informações, mas confirmou aos jornalistas de que não omitia nada. O papel de amante foi assumido por uma mulher, que se disse amante do marido, não da falecida. Disse que sabia que ele era casado e que sentia falta da relação que tinha com ele. O agente da funerária informou que quem ligou foi o marido às $14 \mathrm{~h} 15$, encontrou a falecida deitada na cama com um tiro no peito, o que contradiz 
todos os depoimentos anteriores e, mesmo, o obituário. Afirmou que ela estava sem joias, a arma estava no local, havia muito sangue e que o marido não parecia triste e, segundo ele, sequer chorou. Quanto à prima, esta se mostrou confusa, disse não ter uma boa relação com Zulmira, recebia ameaças dela, mas não queria se meter nesta situação.

Após o encerramento da coletiva de inquérito, encerrei o episódio e abrimos para a roda de conversa. Foi levantado pelos participantes como um importante elemento o figurino. O caráter de investigação foi acentuado e entendido e é importante refletir sobre as incoerências nos elementos apresentados pelos participantes para se compreender todo o contexto do drama. Algumas questões foram levantadas pelos participantes: "Quem matou Zulmira?"; "A morte da falecida foi com tiro ou realmente morreu nos braços do marido?"; "Quem é a loira?". Para que estas discussões não fossem respondidas agora, mas fossem trazidas à tona no próximo episódio, pedi para que eles se detivessem naquilo que tinha, de fato, enquanto registro. Assim, pedi para que todos recordassem do obituário e que este precisaria ser consultado novamente para evitarmos divergências.

\section{Terceiro Episódio}

No terceiro episódio houve a aparição da gaveta como pacote de estímulo composto, além do importante uso da iluminação como convenção teatral para a criação da atmosfera.

Assumi o papel de investigador da perícia. Três conjuntos de evidências foram analisados separadamente pelos três grupos de peritos com seis ou sete integrantes, que emitiram seus relatórios ao final de toda a perícia. Os conjuntos eram os seguintes: 1ㅇ) Gaveta, exame, fitoterápico e orçamento; $2^{\circ}$ ) Carta e notícia; 3으 ) Obituário, relatório policial e dívida.

Todos os grupos de peritos expuseram ao investigador suas constatações do material analisado verbalmente. Neste caso, tomei nota de todas as hipóteses - como professor-atuante investigador - para encontrar consonâncias e contradições.

O estímulo composto inclui diferentes artefatos - objetos, fotografias, cartas e outros documentos, incluídos em um container apropriado. A significância é dada pela justaposição cuidadosa de seu conteúdo - o relacionamento entre eles e o detalhe dos objetos sugere motivação e ação humana. (Somers, 2011, p. 179)

Todos constaram que ela sabia de sua doença grave e que iria morrer, porém alguns acreditavam que ela não havia morrido. Em função de sua salivação, diagnosticaram a falecida como tuberculosa, e também pelo seu constante relato de gosto de sangue na boca, de acordo com a carta que ela escreveu um pouco antes morrer.

No entanto, os participantes levantaram a possibilidade, também, de que o sangramento fosse apenas consequência de algum exame que ela havia feito recentemente, como a broncoscopia, por exemplo, que causa ferimentos na garganta. Outra hipótese levantada pela perícia foi a de desequilíbrio mental de Zulmira, poderia ser vítima de esquizofrenia ou depressão, em função da dívida de jogo de seu marido. Ela sabia que ia morrer, sabia a data de sua morte, por isso fez o orçamento do caixão 
que ela queria. Curiosamente, um grupo de peritos inseriu em seu relatório que a madeira utilizada na fabricação da gaveta é a mesma usada na confecção do caixão, mas não solicitou maiores investigações a esse respeito. Sua médica foi imperita, por isso a perícia solicitou uma análise química do fitoterápico que ela tomava, pois, por unanimidade, a perícia acreditava que o líquido foi adulterado, mesmo não tendo encontrado evidências o suficiente para esta constatação.

Outras hipóteses levantadas pelos peritos foi que seu sonho de ter um funeral luxuoso era maior que sua vontade de tratar a doença. Isto pode ter vindo à tona, principalmente, pela notícia de jornal encontrada na gaveta da falecida. Esta notícia possuía grifos com marca-texto e expressões escritas à caneta como, por exemplo, "Que sonho!". A impressão da notícia foi realizada por ela no dia 21 de junho de 2013.

O velório não aconteceu como ela sonhava, pois ela queria que a prima ficasse com cara de tacho, o que de certa forma foi levantado tanto no velório quanto na coletiva de imprensa. Os depoimentos do marido fazem a perícia desconfiar da veracidade das informações: ele confessa que é viciado em jogos, mas mente sobre outros aspectos como, por exemplo, sobre o dinheiro que podia ter gasto para o velório da esposa, o que faz a perícia acreditar em embolso de dinheiro. O marido desvia a atenção da hipótese afirmando que a esposa tinha gases. $O$ documento sobre a dívida de jogo de azar é adulterado já que ele é ilegal no país, logo seu caráter é colocado em xeque novamente. Apesar de demonstrar tamanha religiosidade, Zulmira sabe há muito que iria morrer e deseja a morte e, talvez, quisesse incriminar a prima de sua desgraça.

A médica também é considerada negligente pelos peritos, pois em seu depoimento afirmou que a paciente não havia morrido do pulmão, mas o laudo médico da radiografia a diagnosticava com nódulos densos. Houve quem desconfiou da veracidade do exame, mas este argumento não foi sustentado pelo corpo de peritos. A médica é considerada uma suspeita pela morte de Zulmira e, inclusive, cogitaram a hipótese de a doutora ser amante do marido de Zulmira. Outra suspeita potencial indicada pela perícia é a prima. Um grupo de peritos excluiu a possibilidade de suicídio, pois a fé manifesta por ela em várias ocasiões não indicava que ela possa ter feito isso. Falou-se também em vingança, envenenamento e vaidade.

Uma perita mais radical preferiu defender sua tese sozinha. Argumentou que Zulmira não morrera e que desejava receber o dinheiro do seguro. Como o caixão estava lacrado durante o velório, não havia como ter certeza de que ela realmente foi enterrada. Como a constante de um funeral luxuoso apareceu em diversos momentos, isto foi considerado um indício de que ela estava viva, queria começar uma vida nova, com outro nome e, por isso, era tudo uma fraude: os exames, as cartas, os laudos e a própria doença. Segundo ela, esta é uma atitude comum entre aqueles que devem muito dinheiro.

Ao término da perícia realizei meu relatório de investigação, o que me fez perceber diversas contradições entre os peritos no que dizia respeito à morte da falecida. Considero importante enunciar quatro das principais teses evidenciadas pela perícia: $1^{\circ}$ ) Morte natural; $2^{\circ}$ ) Suicídio; 3 ㅇ) Morte provocada por outra pessoa; 4 으 Ela ainda estaria viva. 
Diante das diferentes e intrigantes constatações encaminhadas pelos peritos, decidi intervir decididamente nas reflexões para o último episódio. Assim, para que novas evidências fossem suscitadas no que diz respeito à morte da falecida, criei um e-mail em nome de Zulmira da Cruz Miranda Ferreira (zulmiracmferreira@gmail.com), emitindo alguns e-mails para os participantes do processo, no intuito de despertá-los o real e o ficcional para além do episódio em si, que proporcionasse uma discussão em outros espaços de convivência, explorando os espaços concebidos pela tecnologia, conforme a proposta transdisciplinar entre drama e currículo de John Somers.

A relação do drama com tecnologia é mais evidente na concepção de artefatos para uso em atividades ou processos em drama, o projeto e confecção atenderiam um grande número de conteúdos do programa em dois objetivos-chave da tecnologia. Projetar e elaborar, além dos programas de ensino. [...]. Além do uso atual em drama de artefatos produzidos tecnologicamente [...]. Estudantes seriam levados prontamente a explorar ambientes moldados ou objetos. (Somers, 1994, p. 136-138, traduzido por Everton Ribeiro)

Alguns dos destinatários dos e-mails foram escolhidos em função dos papéis que assumiram em algum dos episódios como, por exemplo, o marido, a prima ou uma parenta muito emocionada com a morte dela.

Entre os seis e-mails enviados no intervalo de 35 minutos, dois foram respondidos pelas destinatárias. As respostas foram importantes, pois vieram à tona reflexões das participantes.

Para: Zulmira da Cruz Miranda Ferreira <zulmiracmferreira@gmail.com>

Você está viva !!! Eu sabiaaaaa !!!

Áhh você dá muita importância ao que essas cartomantes falam ...

Figura 1 - E-mail resposta Loira aguada

Para: Zulmira da Cruz Miranda Ferreira <zulmiracmferreira@gmail.com>

27 de julho de 2013 10:20

Fitoterápicos são boas alternativas para um tratamento.
O resultado é a médio e longo prazo, ao contrário de remédios
"comuns" que tem um prazo curto para seu efeito.

Mas, sempre temos que procurar profissionais, e atentar para os laboratórios e prazo de validade do mesmo.

Além de observar o cheiro, o remédio que analisamos no caso "Zulmira" estava adulterado.

Sendo necessário uma analise em laboratório para que seja comprovada tal adulteração.

Já que somente ele poderá comprovar tal adulteração.

Nesse difícil e emaranhado caso, se faz necessário não agir por suposições.

Figura 2 - E-mail resposta Desconfiança 
No dia seguinte ao envio dos e-mails, instalaram-se muitos comentários a respeito, entre os participantes. Fui parado algumas vezes no corredor para receber a informação de que e-mails de Zulmira estavam sendo recebidos, alguns em tom de gracejo, outros em tom de mistério: "Professor, eu recebi um e-mail da Zulmira"; "Professor, tem gente que recebeu e-mail da Zulmira". Eu limitava minha resposta às seguintes expressões: "Sério?" ou "Como assim?". Como achei difícil sustentar a realidade do conteúdo dos e-mails até o próximo episódio, sem que desconfiassem de que era eu quem havia enviado, decidi encontrar um pretexto para expor coletivamente o ocorrido. Desta forma, escrevi um e-mail da Zulmira para meu endereço eletrônico institucional - e-mail em que os estudantes costumavam me contatar.

Cuidado!
1 mensagem
Zulmira da Cruz Miranda Ferreira <zumiracmferreira@gmail.com>
Para:
É melhor você parar de brincar com fogo.

Figura 3 - E-mail Cuidado

A decisão de criar e escrever os e-mails foi fundamental para instaurar o ficcional para além de cada episódio. A curiosidade para compreender o encerramento do episódio foi fundamental para a composição de um roteiro cênico e por minha escoIha pela aparição de uma personagem-chave para finalizar as especulações: a mãe de Zulmira. A mãe da falecida não foi um papel trazido para o drama, em nenhum momento, apesar de ela ter sido citada tanto no velório quanto no inquérito da perícia. Assim, acreditei que a resolução de algumas contradições do processo podia ser proporcionada por ela, que tinha um contato inquestionável com a falecida. Como eu já havia proposto que o último episódio seria o da cartomancia, o papel de cartomante seria central para os desencadeamentos. Decidi, então, criar um roteiro cênico para a intervenção de duas personagens: a cartomante e a mãe - durante o episódio. Este roteiro é claramente baseado na primeira cena da peça de Nelson Rodrigues.

\section{Quarto Episódio}

Para conseguir conceber uma cena dentro do episódio, foi necessário ensaiá-la e recorrer aos signos que compõem o teatro. Sendo assim, eu precisava da atuação de uma pessoa externa ao processo, de uma mulher que surgisse como mãe da falecida e interviesse na ação. Convidei minha colega de trabalho para representar esta personagem. Como ela não é atriz, relutou um pouco no início, pois não sabia se tinha concentração o suficiente para não "rir" da cena. Eu expliquei bastante a ela sobre a importância da cena e sobre a espontaneidade com a qual ela poderia representar, portanto se ela se desconcentrasse isto não seria um problema, pois 
poderia ser compreendido como uma característica da personagem. Ela aceitou a proposta. Levei o roteiro a ela e ensaiamos durante uma tarde inteira, um dia antes do episódio. Ela trouxe várias ideias de composição, de marcações de cena, ficou bem à vontade para criar a personagem como quisesse. Eu interferi bastante na decupagem do texto, nas intenções de cada fala, para que a interpretação determinasse muito das incógnitas do drama até então. Lembro-me da primeira intervenção criativa dela quando, após ler o roteiro, ela disse convictamente: "Eu achei o texto bem legal, mas aqui no final eu não vou entregar cinquenta reais não. Eu vou dizer que sua consulta não vale nem cinquenta centavos e vou te entregar a moeda". Eu não questionei a mudança que ela faria no texto, mesmo porque ela estava super coerente com os impulsos da personagem. Realmente ela fez isso na cena do episódio e grande parte dos participantes considerou o ato muito engraçado. Percebam que neste episódio eu considero que, pela primeira vez no processo, construímos uma personagem. De acordo com Heloise Baurich Vidor, há diferença entre ser professor no papel e professor-personagem. O professor no papel está mais próximo do que se entende em inglês por teacher-in-role, deste professor que assume papéis sociais ao longo do drama. Desta forma, no quarto episódio, posso dizer que eu e minha colega ocupamos o status de um professor-personagem.

O professor-personagem dá ênfase à caracterização, cria um discurso condizente com as circunstâncias do personagem em termos de época, nacionalidade, ideologia, criando assim uma individualidade, enunciando o texto literal de um autor seja ele dramático ou não. Durante o processo do drama este personagem interage nas improvisações do grupo, mantendo, porém, sua postura física e ideológica a fim de permitir o desenvolvimento de uma contra argumentação pelo grupo. (Vidor, 2008, p. 16)

Ao longo dos ensaios, eu e minha colega marcamos algumas ações que contribuíssem para criação da tensão na cena e, consequentemente, no episódio. Quando os participantes chegaram, ela já estava presente na caixa preta. Nós conversávamos e alguém até brincou: "Ah, a professora que é a Zulmira?". Demos risada e terminamos de combinar algumas coisas. Para todos os efeitos, a professora só estava ali para me auxiliar com o material do cenário. Pedi o auxílio do pessoal para afinarmos as luzes e montarmos o cenário. A casa da cartomante era pequena, criamos um quadrado com biombos para estabelecer a delimitação. Propositalmente, pedi para que montássemos próximo do canto em que havia a porta de serviço. Esta seria a porta da casa da cartomante. Distribuímos cadeiras no espaço, rentes aos biombos, número suficiente para que todos estivessem sentados.

Antes de iniciar o episódio, minha colega já não estava mais na caixa preta. Eu havia pedido a ela para que ficasse escondida na cabine de som e iluminação, já que ninguém subiria até lá durante o episódio. Durante este tempo, ela se caracterizou. Eu pedi para que todos aguardassem na caixa preta, pois eles saberiam quando o episódio teria começado. Fui para o camarim e me vesti de cartomante. Coloquei um lenço na cabeça e um xale roxo, o mesmo xale que já havia sido figurino da cartomante em outro episódio. A câmera estava posicionada em uma das diagonais. $O$ espaço cênico já estava organizado, os refletores em foco, as cadeiras em volta, a 
mesa com uma toalha, um baralho velho e uma jarra de água com copo. A deixa para que a mãe de Zulmira batesse à porta era, justamente, quando a cartomante dissesse que precisava beber um copo d'água.

O episódio começou da seguinte maneira. Entrei pela porta - como cartomante - com bastante apreensão. Disse a todos: "Pode entrar! Entrem!". A ocupação do espaço foi bem breve, na verdade. Todos estavam esperando por algum acontecimento. Depois que todos se acomodaram, eu também sentei à mesa e disse algo do tipo: "Eu só aceitei a proposta de receber vocês aqui porque vocês disseram que iam pagar bem, e eu estou precisando de dinheiro. Eu não queria receber tanta gente porque outro dia eu fui em cana. Mas está todo mundo aqui, né? Não vai chegar mais ninguém?!". Eles assentiram. O comportamento da cartomante era de muito nervosismo, ela pedia constantemente silêncio e queria tudo às pressas. Comecei a embaralhar as cartas e perguntei quem queria ser o primeiro. Como eu quis deixar bem claro o charlatanismo da cartomante, as previsões que eu fiz, beiravam à lógica clownesca, daquela lógica avessa à estabelecida. Então as previsões eram óbvias, mas bem convincentes, do tipo: "Tem uma mulher morena na sua vida, cuide bem dela, ela está do seu lado". Eu li as cartas apenas para três pessoas antes da entrada da mãe da falecida. Lembro-me que uma das participantes, coincidentemente, em apenas duas fileiras de cartas postas sobre à mesa, retirou 3 reis e 3 valetes. Lembro-me de ter dito: "Nossa, tem muito homem na sua vida. Alguns mais novos, outros mais velhos, de todos os tipos. Cuidado com eles! Foca no seu trabalho". Todos achavam tudo muito engraçado. Após uma outra previsão, decidi tomar o copo d'água, para que o momento de tensão fosse instaurado, com a entrada da mãe da falecida, que bate à porta insistentemente. Exclamei: "Meu Deus do céu, eu falei que não era pra vir mais ninguém. Já tem muita gente aqui, vocês chamaram mais alguém?". Uma das participantes me replicou dizendo que eu estava muito nervosa. Eu retruquei: "É claro! Vocês acham que é bom ir pra cadeia?". A mãe de Zulmira bate insistentemente na porta. Escondi o baralho embaixo da toalha e fui atender a porta.

Para ler a sorte, eu estabeleci algumas convenções de significados das cartas. Então para dizer que tinha uma mulher morena na vida da pessoa, era necessário sair na leitura uma dama de paus ou de espadas, ou seja, dos naipes pretos. Na hora da leitura para a mãe, eu tirei metade do baralho para que aparecesse finalmente uma das damas pretas. Era ridículo tanto pela falta de critério de quantidade de cartas que eram exibidas quanto pela agressividade com a qual eu distribuía as cartas pela mesa, algo próprio da tensão em que a personagem estava e transmitia para seus consulentes.

Após o escândalo causado na saída da mãe de Zulmira, os participantes começaram a coagir Madame Crisálida, para entender o porquê ela estava tão nervosa. Disseram muitas coisas, sobre o estado em que ela estava, das ameaças que a mãe fez a todos, inclusive levantaram a hipótese de elas estarem escondendo o corpo de Zulmira na casa dela. Fatalmente o constante discurso de medo da polícia contribuiu para esta leitura dos participantes. Começaram a perguntar sobre o envolvimento dela com a família da Zulmira, com o marido. Eu dizia que não o conhecia, que ela havia sido consultada apenas uma vez por mim. Eles disseram que estavam ligando algumas coisas, disseram que tinham visto algumas homeopatias quando entraram 
na minha casa, se eu havia receitado algum remédio para ela. Eu neguei todas as coações. Alguns ficaram em silêncio boa parte do tempo, mas teve gente que dizia que a história estava muito mal contada. Li as cartas mais uma vez para tentar responder quem matou Zulmira, foi o que eles pediram. Fiz um breve resumo de todos os últimos acontecimentos antes de sua morte, através das cartas: a saúde dela estava comprometida, uma médica que deixou de ajudá-la, desgosto provocado pelo marido, a prima invejosa novamente, tinha desistido da vida. Começou-se uma discussão sobre o envolvimento, sobre a investigação da polícia, as entrevistas, sobre a qualidade do velório. Houve uma crise de riso quando a Madame Crisálida disse: "Todo mundo tava falando do velório dela, tavam tirando sarro no bairro. Imagina, apareceu até no jornal que ela ia ter um enterro luxuoso". O marido tentou se justificar dizendo que não fez um velório melhor porque não deixaram abrir o caixão, não deixaram que ele visse sua mulher. No entanto, eu o questionei já que todos sabiam que ele nem havia aparecido no dia do velório. Eu finalizei dizendo que eu não tinha nada a ver com isso, que meu depoimento estava na polícia e que se quisessem era só levantar minha ficha. E pedi para todos se retirarem.

Após o encerramento, todos voltaram para o espaço, e pedi para que dissessem se eles compreendiam o que havia acontecido no final das contas. $O$ envio dos e-mails veio à tona, alguns achavam que era a cartomante, outros que era a mãe e outros que era o marido quem enviara os e-mails. Não houve, realmente um consenso. Afinal "o problema introduzido é raramente direto; se o fosse perderia a multidimensionalidade requerida para sua eficácia" (Somers, 2011, p. 178). Neste sentido, percebo que a pluralidade de leituras é muito compreensível e permitida num processo de drama, tendo em vista que a dramaturgia surge dos elementos da história e deles emergem o caráter investigativo e as potencialidades do processo.

Quanto maior a naturalidade com que o narrador renuncia às sutilezas psicológicas, mais facilmente a história se gravará na memória do ouvinte, mais completamente ela se assimilará à sua própria experiência e mais irresistivelmente ele cederá à inclinação de recontá-la um dia. (Benjamin, 1994, p. 204)

Destarte, estabeleceu-se, a partir desta narrativa, a concretização do narrador proposto por Benjamin, no que diz respeito, principalmente, à naturalidade e à experiência.

\section{Considerações Finais}

A dramaturgia escolhida ("A falecida, de Nelson Rodrigues) como pré-texto para a concepção de um process drama expõe situações-limite de sofrimento. Como o pré-texto explora um conflito cotidiano em suas tragédias cariocas, Nelson Rodrigues se popularizou por ser também bastante familiar à ficção (e também muito de realidade) jornalística. A ironia está presente em "A falecida" e fica evidente quando o próprio autor questiona o gênero de sua peça, que não abre mão de uma "tristeza fundamental", do gênero trágico. Para tornar a discussão ainda mais irônica, como aponta Magaldi (1992), compara o riso diante das desgraças de Zulmira uma imoralidade, tanto quanto uma "missa cômica". 
A ironia não é explícita e sim implícita, tanto na dramaturgia quanto no processo de drama. Isto possibilita a proposição bastante ativa dos participantes, evocando contradições, ulttrapassando os limites do convencional. Concordamos com uma ideia de Gilles Deleuze, que sugere a importância de uma aula permitir colocar uma matéria em movimento. O autor também afirma a importância do aluno não ser forçado a aderir a uma "escola de pensamento", assim estando aberto a novos encontros. Como assevera Pelbart (2005, p. 10): "uma escola é todo o contrário de um movimento. Uma escola tem chefes, gerentes, administradores, juízes, tribunal, exclusões etc. Um movimento tem derivas, bifurcações, linhas de fuga" (Pelbart, 2005, p. 10). O interesse deste trabalho esteve focado numa formação plural, aberta aos trânsitos e às contradições.

A pesquisa-ação se configura como uma importante abertura de novos encontros. Mesmo não sendo hegemônica na universidade, tem buscado a legitimação dos/ nos espaços populares no interior do ambiente acadêmico, conforme as demandas dos grupos minorados, articulando interesses dos pesquisadores e produção de conhecimento. O maior ganho da pesquisa-ação é a descentralização do conhecimento, da interação e intervenção de diferentes leituras de mundo, no intuito de ruptura do habitus como mecanismo de controle, abrindo a outros possíveis.

O drama como experiência pode ser legitimado no campo pedagógico enquanto experiência estética. Na língua inglesa, aesthetic (estética) é antônimo de anaesthetic (anestésico). Se anestésico significa interromper sentidos, inibindo impressões, a experiência estética opera os sentidos ao máximo. Trata-se de explorar a presença para debater e se posicionar sobre qualquer tema que seja inquirido, significa estar vivo!

Com o drama, o professor distancia-se do que fora preestabelecido, das normativas, buscando soluções ficcionais, mas, consequentemente, "verdadeiras". Assim, lançamo-nos nesta aldeia das incertezas, pois concebemos que "o espectro do pós-modernismo assombra os lugares anteriormente sagrados" (Green; Bigum, 2008, p. 213), logo é necessário criar um processo de escolarização que possa evitar o alienigenismo. Um alienígena não estabelece comunicação, desta forma é não se chega sequer à beira de uma experiência. Esperamos, com este trabalho, romper com uma postura não-comunicativa, partindo em direção de uma experiência.

Em boa parte da trajetória como estudantes, em todos os níveis educacionais, somos colocados no lugar de alienígenas: ignorados, incompreendidos, incomunicáveis. Boa parte dos docentes tornam isto um habitus, como se não fosse nenhum problema ser um professor alienígena. Em tempos de tantas probematizações sobre evasão escolar e desinteresse dos educandos, compreendemos que é momento de termos coragem de reconhecer quão descontextualizada é a reprodução. Urge reconhecer a importância de proporcionar que estudantes estejam num espaço escolar não por obrigação, mas mobilizados pela criação, recriação e vontade de modificar seu contexto, com sensibilidade e experiência. Pensamos serem necessárias novas pesquisas neste âmbito, da mesma forma que defendemos, enquanto artistas, no estado orgânico, no treinamento e na metaestabilidade de um processo de criação. Concordando com Deleuze, Pelbart reitera que "não lhe importa a cultura, muito 
menos a erudição, mas estar à espreita dos encontros, com uma ideia, com uma obra, com uma cor" (Pelbart, 2005, p. 10).

\section{Referências}

BENJAMIN, Walter. Magia e técnica, arte e política: ensaios sobre literatura e história da cultura. Trad. Sérgio Paulo Rouanet. 7. ed. São Paulo: Brasiliense, 1994.

BOURDIEU, Pierre. Entrevistado por Maria Andréa de Loyola. Rio de Janeiro: EDUERJ, 2002.

BOURDIEU, Pierre; PASSERON, Jean-Claude. A reprodução: elementos para uma teoria do sistema de ensino. Trad. Reynaldo Bairão. 4. ed. Petrópolis: Vozes, 2011.

BRASIL. Parâmetros curriculares nacionais: arte. Secretaria de Educação Fundamental. 2. ed. Brasília: MEC/SEF, 1997.

CABRAL, Beatriz Ângela Vieira. A tensão como pivô da experiência em drama. In: CONGRESSO DE PESQUISA E PÓS-GRADUAÇÃO EM ARTES CÊNICAS, 6., 2010, São Paulo. Anais do VI Congresso de Pesquisa e Pós-Graduação em Artes Cênicas (Memória ABRACE Digital). São Paulo: USP, 2010, p. 1-5.

CABRAL, Beatriz Ângela Vieira. Drama como método de ensino. São Paulo: Hucitec, 2006.

CABRAL, Beatriz Ângela Vieira. O professor-artista: perspectivas teóricas e deslocamentos históricos. Urdimento, Florianópolis, v. 1, n. 10, p. 35-44, dez. 2008.

CHEKHOV, Michael. Para o ator. 2. ed. São Paulo: Martins Fontes, 1996.

COHEN, Renato. Performance como linguagem. 2. ed. São Paulo: Perspectiva, 2004.

FIGUEIRA, Pedro de Alcântara. A educação de um ponto de vista histórico. Intermeio, Campo Grande, v. 1, n. 1, p. 11-15, 1995.

FREIRE, Paulo. Pedagogia da autonomia: saberes necessários à prática educativa. 34 . ed. São Paulo: Paz e Terra, 1996.

GONÇALVES, Nadia Gaiofatto.; GONÇALVES, Sandro Aparecido. Pierre Bourdieu: educação para além da reprodução. Petrópolis: Vozes, 2010.

GREEN, Bill; BIGUM, Chris. Alienígenas na sala de aula. In: SILVA, Tomaz Tadeu da. (Org.) Alienígenas na sala de aula: uma introdução aos estudos culturais em educação. 7. ed. Petrópolis, RJ: Vozes, 2008. p. 208-243.

GUSMÃO, Neusa Maria Mendes. Desafios e diversidade na escola. Revista Mediações, Londrina, v. 5, n. 2, p. 9-28, jul./dez. 2000. 
LARROSA, Jorge. Notas sobre a experiência e o saber da experiência. In: SEMINÁRIO INTERNACIONAL DE EDUCAÇÃO DE CAMPINAS, 1., 2001, Campinas. Revista Brasileira de Educação. Campinas: UNICAMP, 2002, p. 20-28.

LYOTARD, Jean-François. A condição pós-moderna. São Paulo: José Olympio, 2002.

MAGALDI, Sábato. Nelson Rodrigues: dramaturgia e encenações. 2. ed. São Paulo: Perspectiva, 1992.

MERLEAU-PONTY, Maurice. O corpo como expressão e a fala. In: MERLEAU-PONTY, Maurice. Fenomenologia da percepção. São Paulo: Martins Fontes, 1996.

NEELANDS, Jonothan. Structuring drama work. Cambridge University Press, 1990.

O'NEILL, Cecily. Da alienação à interpretação: os usos da ironia. Trad. Beatriz Ângela Vieira Cabral. Urdimento, Florianópolis, v. 1, n. 8, p. 7-18, dez. 2006.

PELBART, Peter Pál. Deleuze e a educação. In: ABRAMOWICZ, Anete; SILVÉRIO, Valter Roberto. (Org.). Afirmando diferenças. Campinas: Papirus, 2005, p. 9-11.

RIBEIRO, Everton. Para evitar o alienigenismo: uma proposta de process drama através da mediação irônica do professor-personagem. Anais do XI Congresso Nacional de Educação, Curitiba/PR, 23 a 26 de 2013, p. 26255-26266.

RIBEIRO, Everton; SILVA, José Francisco Quaresma da. O Teatro reinventa a realidade: ação docente, experiência estética e indissociabilidade entre ensino, pesquisa e extensão no Instituto Federal do Paraná. TEATRO: criação e conhecimento [online], Palmas/TO, v.2, n.3, p. 30-38, jul/dez, 2014.

RODRIGUES, Nelson. Teatro quase completo de Nelson Rodrigues. Rio de Janeiro: Tempo Brasileiro, 1965.

SOMERS, John. Drama in the curriculum. London: Cassel, 1994.

SOMERS, John. Narrativa, drama e estímulo composto. Trad. Beatriz Ângela Vieira Cabral. Urdimento, Florianópolis, v. 1, n. 17, p. 175-185, set. 2011.

VIDOR, Heloise Baurich. O professor assume um papel e traz, por que não, um personagem para a sala de aula: desdobramentos do procedimento teacher in role no processo de drama. Urdimento, Florianópolis, v. 1, n. 10, p. 9-17, dez. 2008. 